\title{
LITHOLOGIC COLUMN OF THE "ARKOMA" DRILLHOLE AND ITS RELATION TO THE CAJON PASS DEEP DRILLHOLE
}

\author{
Leon T. Silver and Eric W. James
}

Division of Geological and Planetary Sciences, California Institute of Technology, Pasadena, California

\begin{abstract}
The $1795 \mathrm{~m}$ "Arkoma" Federal 1-26 well, $48.5 \mathrm{~m}$ from the Cajon Pass Deep Drillhole (CPDDH), provides additional lithologic and structural data pertinent to that project. Basement surface was encountered $158 \mathrm{~m}$ deeper than in the CPDDH. Rock units correlate well between the holes; the offset persists to $1128 \mathrm{~m}$. Below this depth both lithologic unit thicknesses and fault zones correlate between holes on subhorizontal projections. A combination of previously unrecognized high-angle and low-angle faults of several ages are required to explain the structures. Blind low angle faults may be regionally important.
\end{abstract}

\section{Introduction}

"Arkoma" Federal 1-26 is located $48.53 \mathrm{~m}$ (159.23 feet) $\mathrm{S5}^{\circ} 30^{\prime} 06^{\prime \prime} \mathrm{W}$ from the DOSECC Cajon Pass Deep Drillhole and was drilled by Arkoma Production Company during 1984. This hydrocarbon exploration well targeted Vaqueros (?) Formation which underlies the Cajon Formation in isolated patches a mile west of the drillsite. Vaqueros Formation (?) in Cajon Pass has been correlated with similar rocks in the Cuyama Valley $210 \mathrm{~km} \mathrm{NW}$ on the opposite side of the San Andreas fault, where it is a major oil producer.

The collar elevation is $997 \mathrm{~m}$ ( $3272 \mathrm{feet})$ above m.s.1. The well reached a depth of $1795 \mathrm{~m}$ but did not encounter hydrocarbons. For scientific purposes the U.S. Geological Survey assumed responsibility for the Arkoma well, the drill pad on which it is located, and use permits governing further operations. At one point the well was considered a candidate for deepening; technical considerations involving its diameter and configuration ruled out the possibility. Maximum deviation from the vertical reached $14.5^{\circ}$ and the bottom of the well is about $220 \mathrm{~m} \mathrm{SE}$ of the collar (Figure 1).

The Cajon Pass Deep Drillhole (CPDDH), "DOSECC" Federal 2-26 utilized an expanded and slightly raised version of the same drillpad. The older well provided a base of information which led, in part, to the selection of that location. Geophysical logs, cuttings and a short $(30 \mathrm{~cm})$ core sample from the bottom of the hole were available for study. The U.S.G.S. has measured an equilibrium temperature gradient for the Arkoma hole (Lachenbruch and Sass, this volume).

In the initial phases of drilling CPDDH, a survey of the Arkoma cuttings and core was compared with materials from the new hole (Silver and James, this volume). With insights from the latter a lithologic column was synthesized for the older well. A comparison of this column with the DOSECC column offers useful information on the continuity of lithologic units and the local geologic structure.

A plan view projection of the relative geometries of the two holes is shown in Figure 1 . The paired numbers indicate measured depth/true vertical depth. Text references are measured depths. The lines between the paths of the two holes tie equivalent elevations. The trace of a vertical plane through the collar of DOSECC-Federal 2-26 and the bottom of ArkomaFederal 1-26 trends S21E. Figure 2 presents data for the two holes projected into this plane.

Copyright 1988 by the American Geophysical Union.

Paper number 8L7363.

0094-8276/88/008L-7363\$03.00

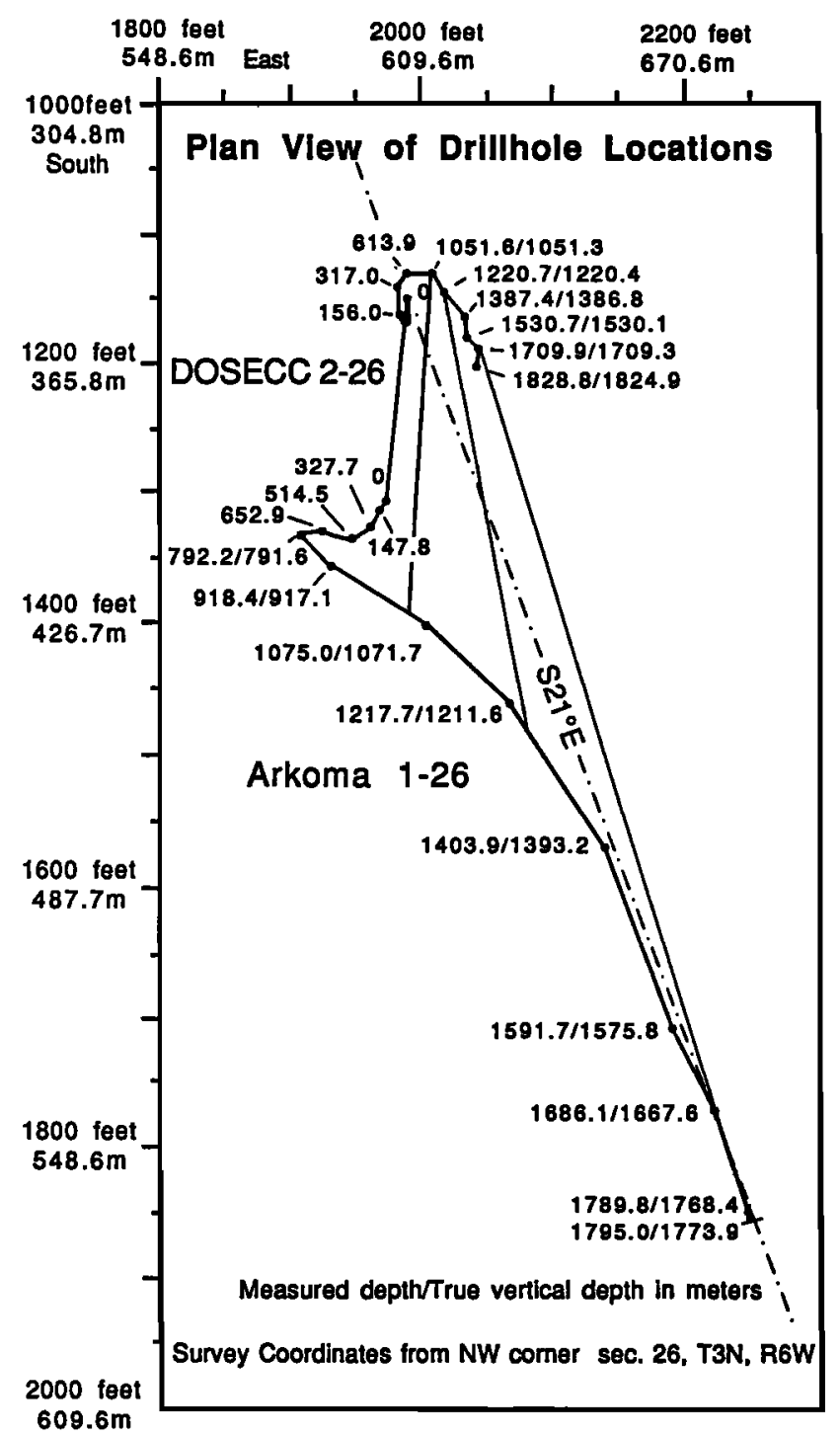

Fig. 1. Plan view of DOSECC (\#2) and Arkoma (\#1) drillholes showing measured and true vertical depths (MD/TVD) of survey points.

The relative position of the two wells in this plane is shown by the position of the inner or adjacent side of each column. The collar elevation of the Arkoma well is about $2 \mathrm{~m}$ lower than that of CPDDH. The base of the Arkoma well has true vertical depth of $1774 \mathrm{~m} 207 \mathrm{~m} \mathrm{S18E}$ from a comparable depth in CPDDH.

\section{Methods}

Cuttings from the Arkoma hole were provided by A. Lachenbruch and J. Sass, U.S.G.S. A segment of the bottom hole core was provided by T. Henyey, U.S.C. Thin sections 
Relative Positions of the

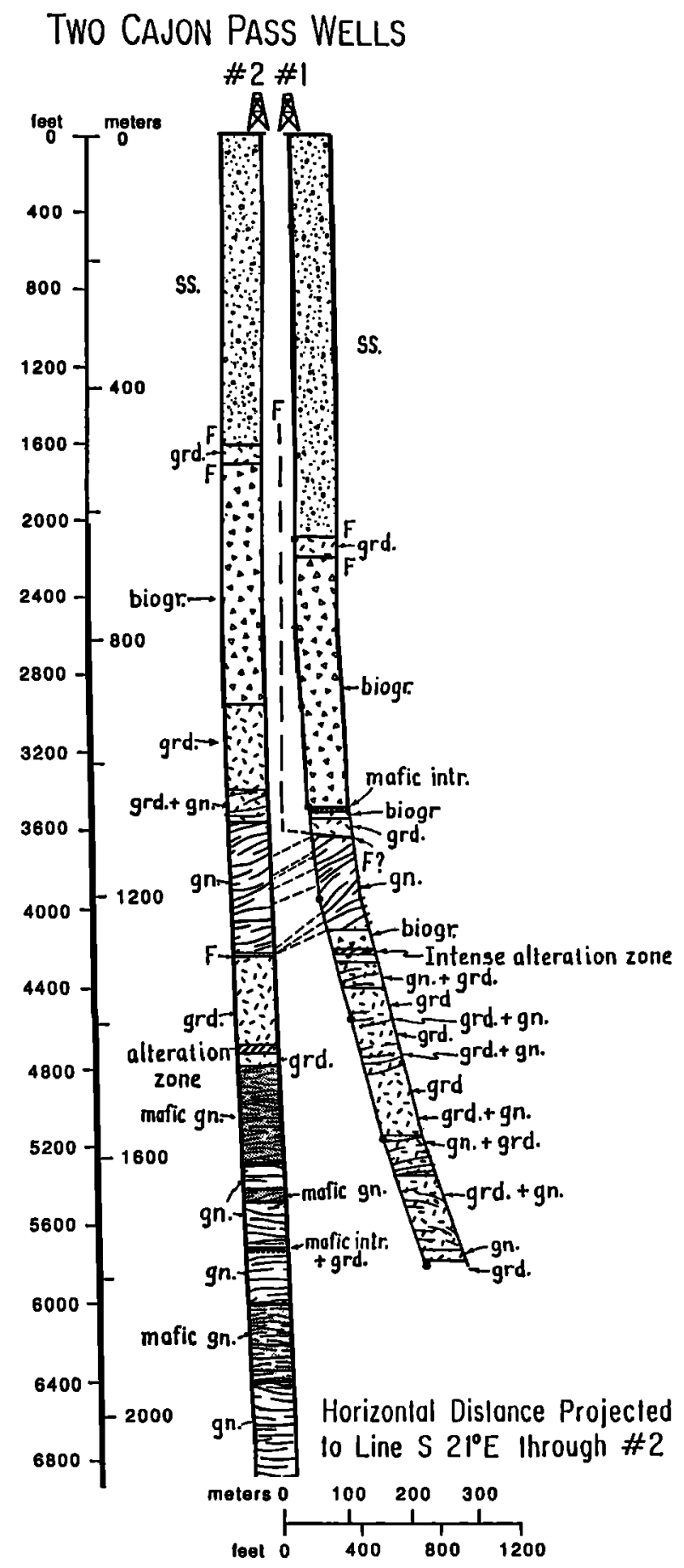

Fig. 2. Cross section and lithology of DOSECC (\#2) and Arkoma (\#1) drillholes. Abbreviations: biogr., biotite granite to augen gneiss; F, fault; gn, gneiss; grd., granodiorite; intr., intrusion; SS., sandstone, mudstone and conglomerate.

were made from the core. The cuttings (typically $<2 \mathrm{~mm}$ diam.) from selected depths were washed and examined with a binocular microscope. Direct comparisons were made with the cuttings to the CPDDH. Both sets of cuttings contain variable percentages of debris derived from the higher parts of the uncased holes. Corrections were attempted based on monitoring distinctive lithologies.

\section{Cuttings Observations and Inferred Arkoma Lithologic} Column

Cuttings from the Arkoma hole show that arkosic sandstone with minor mudstone makes up the first $655 \mathrm{~m}$ of the hole (Figure 2). Medium-grained biotite granodiorite was encountered between $655 \mathrm{~m}$ and $686 \mathrm{~m}$ followed by coarse porphyritic biotite granite to $1097 \mathrm{~m}$. Between $1097 \mathrm{~m}$ and 1128 m medium-grained hornblende-biotite granodiorite was sampled. Below an inferred fault contact at $1128 \mathrm{~m}$, biotite granite gneiss, muscovite-biotite paragneisses, and biotite quartzite with sillimanite were sampled to about $1262 \mathrm{~m}$. Between $1262 \mathrm{~m}$ and about $1314 \mathrm{~m}$ the rock is granitic with a large alteration zone at $1295 \mathrm{~m}$. At $1314 \mathrm{~m}$ biotite sillimanite gneiss is sampled again and interfingers with sphene-biotite granodiơrite by $1341 \mathrm{~m}$. Granodiorite continues from $1341 \mathrm{~m}$ to $1490 \mathrm{~m}$ with an interval containing biotite sillimanite gneiss between $1402 \mathrm{~m}$ and $1433 \mathrm{~m}$. From $1490 \mathrm{~m}$ to $1585 \mathrm{~m}$ an interval of mixed paragneiss, granodiorite, and mafic gneiss is followed by $43 \mathrm{~m}$ of biotite sillimanite gneiss. From $1628 \mathrm{~m}$ to the bottom of the hole at $1795 \mathrm{~m}$ cuttings are sphene-bearing hornblende-biotite granodiorite with intervals of dioritic and mafic gneiss (1631-1652 m, 1673-1679 m, 1707-1710 m, $1765-1771 \mathrm{~m}$ ) and intervals of granodiorite gneiss with paragneiss. Core near the bottom of the hole $(1791 \mathrm{~m})$ is weakly foliated and slightly sheared sphene-homblende-biotite granodiorite with sparse 1 to $2 \mathrm{~cm} \mathrm{~K}$-feldspar megacrysts, several $\mathrm{cm}$-thick pegmatitic segregations, and thin $(0.1 \mathrm{~mm})$ fracture filling veinlets of zeolite.

\section{Comparison of Arkoma and Cajon Pass Drillhole Columns}

Almost all basement lithologies in the Arkoma hole can be cross-correlated with the DOSECC hole lithologies. However, significant differences in depths were noted down to about $1097 \mathrm{~m}$ true vertical depth. Below $1097 \mathrm{~m}$ lithologies and physical parameters recorded in the Arkoma geophysical logs suggest approximate equivalence of lithologies with depth allowing for plausible lateral variations as the two wells diverge with increasing depth.

Comparison of the lithologic columns from the "Arkoma" well and CPDDH (Silver and James, this volume) show a 158 m difference in depth for the sediment-basement contact (Figure 3). This difference in depth of the contact and the 48 $m$ distance between the two wells requires a steep fault $\left(>73^{\circ}\right)$ between the wells at that level. The vertical position of an intersection of this fault with either column cannot be determined uniquely, but the lithologic and gamma ray logs provide important constraints. In both holes the sequence and thickness of basement rock units includes about $30 \mathrm{~m}$ of hornblendebiotite granodiorite in fault contact above $396 \mathrm{~m}$ of distinctive allanite-sphene-biotite granite. The basal contact of this granite in both holes is with a second sphene-homblende-biotite granodiorite. These units, down to $917 \mathrm{~m}$ in the CPDDH and about $1082 \mathrm{~m}$ in the Arkoma hole, are also offset about $158 \mathrm{~m}$. Gamma ray variations in mixed gneiss and granodiorite below $1148 \mathrm{~m}$ in the CPDDH match well with radioactivity patterns logged in similar gneisses below $1128 \mathrm{~m}$ in the Arkoma hole. At this depth the two holes are about $87 \mathrm{~m}$ apart. The $\sim 20 \mathrm{~m}$ depth difference between correlative gamma ray log variations is in the opposite sense of the inferred fault offset of the shallower units and might represent a dip component $\left(>13^{\circ}\right.$, undefined strike) of gneissic layering. Therefore, we infer that a fault between the two holes may cut through the Arkoma hole below the offset correlative units and above the gamma ray correlation at $1128 \mathrm{~m}$. It would pass through the granodiorite (grading to gneiss with depth) below the granite in the Arkoma well, truncating it to $49 \mathrm{~m}$ compared to $183 \mathrm{~m}$ exposed in the CPDDH. This fault is plausibly but not uniquely correlative with the steep fault which offsets the sediment-basement contact. We suggest in Figure 2 an interpretation that this is a 


\section{ALTERNATIVE FAULT INTERPRETATION}

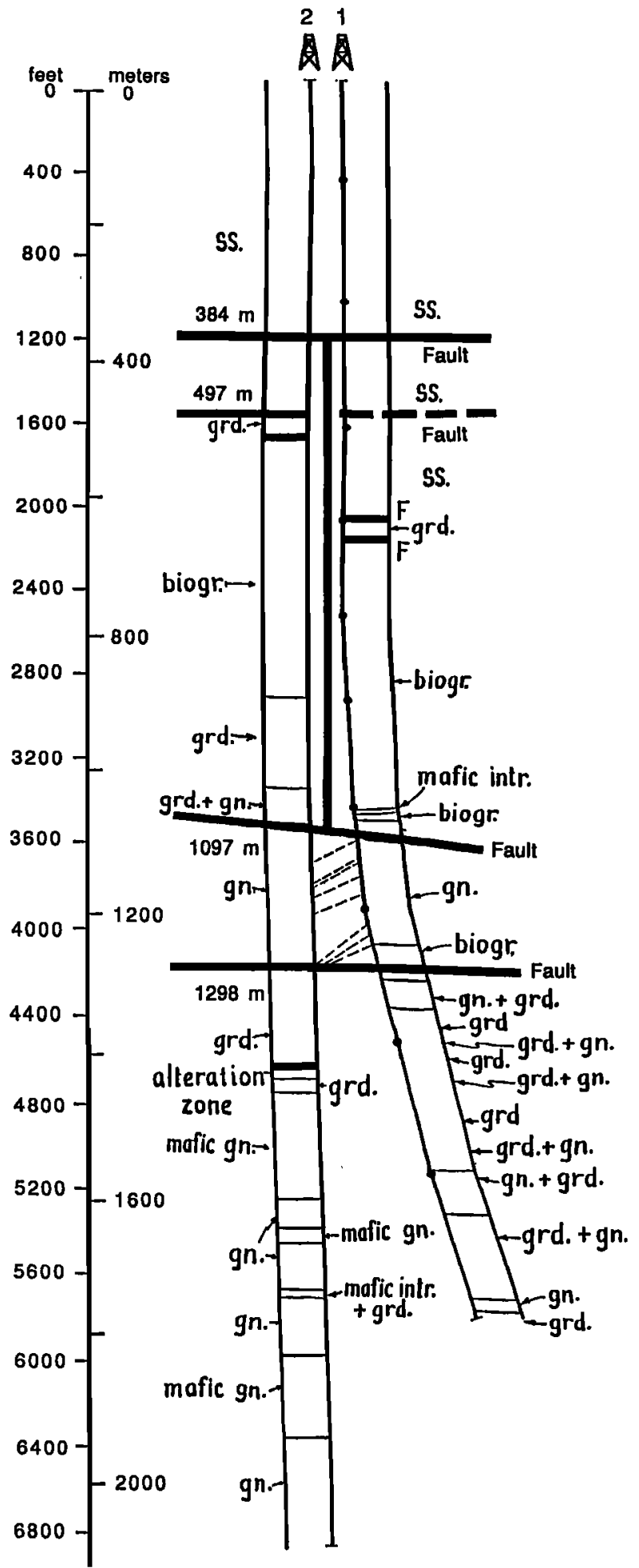

Fig. 3. Alternative interpretation of faults in the DOSECC (\#2) and Arkoma (\#1) drillholes. Abbreviations as in Figure 2.

steep, south-dipping normal fault which may intersect the CPDDH in the sedimentary section. However, other projections are possible.

The strike of the fault is not well established by the twopoint constraints presently available. However, local and regional fold and fault trends are predominantly in the $\mathrm{NW}$ quadrant. As Pezard et al. (this volume) have noted, a plausible trend for the fault could fall in that quadrant. Indeed they have developed alternative and contrasting models in which the top of the basement between the well is offset by a NNW. trending, east-dipping reverse fault system related in sense to the Squaw Peak and Whale Mountain thrust faults and consistent with localization of folding in the Cajon Formation near these faults

We recognize the present non-uniqueness of various structural interpretations. For example, the steep fault cutting the basement contact need not extend further than its consistent offset can be traced. There is no compelling evidence for large vertical offsets in the upper $366 \mathrm{~m}$ of the sedimentary column. The resistivity logs suggest an element of anomalous sedimentary section in the Arkoma well between about $488 \mathrm{~m}$ and $655 \mathrm{~m}$ opposite the top of the DOSECC basement (Pezard, et al., this volume). Between $366 \mathrm{~m}$ and $497 \mathrm{~m}$ in both wells, and especially at about $384 \mathrm{~m}$ where dips abruptly change from steep to near horizontal (Pezard, et al., this volume), younger low-angle faults related to the Squaw Peak system, which do not reach surface, may intercept and offset an older steep basement-disrupting fault. This would explain the lack of evidence for a large displacement in the upper $366 \mathrm{~m}$. The steep dips, folds and faults in the upper sedimentary section may be completely decoupled from the underlying structures. Similarly, the fault which we postulate in the Arkoma hole near $1097 \mathrm{~m}$ may not be the extension of the steep vertical fault shown in Figure 2. Instead the truncation of the granodiorite interval near $1097 \mathrm{~m}$ in the Arkoma well may be the product of a sub-horizontal fault which passes unrecognized through the gneisses in the DOSECC well at that general depth. A sketch of this alternative is offered in Figure 3.

We share the view that unexposed low-angle faults play an important role in the local and regional structure (Meisling and Weldon, in press). As a candidate, we would suggest the major fault zone at $1298 \mathrm{~m}$ in the DOSECC well correlates with the intense alteration zone at $1311 \mathrm{~m}$ in the Arkoma hole (Figure 3). The true attitude of such inferred low-angle faults cannot be obtained from our two-point intersection. Such low-angle faults are consistent with numerous observations on low-angle foliations and other metamorphic structures described in the DOSECC cores (Silver and James, this volume). Metamorphic structures are inferred to be Cretaceous and older. However, as modelled here the low-angle faults must be younger than the middle to late Miocene Cajon Formation with which they are involved. If related to the Squaw Peak fault, they are late Miocene or earliest Pliocene. They may relate instead, to more recent structural developments in the vicinity of the San Andreas fault. We cannot assign ages to individual faults but clearly there is more than one generation. The low-angle faults which bound the top granodiorite unit must be older that the high-angle fault offsetting the basement contact. Recent reactivation of the low angle fault separating the basement and sedimentary sections is also plausible. As indicated in Figure 3, an extension of this fault may separate the sedimentary section with anomalous resistivity from higher strata in the Arkoma hole.

In our discussion of structures and lithologies in the DOSECC well (Silver and James, this volume) we have noted the remarkable diversity and the abrupt discontinuities in that column. A similar quality is observed in the Arkoma well. The youngest plutonic units in both wells (the weakly foliated granodiorites) may, perhaps, represent several distinct subhorizontal intrusive sheets. On the other hand, when the apparent vertical offsets are restored, a distinct horizontally stratified character involving several lithologies and large nearhorizontal faults emerges. From our close examination of both wells we are left with the impression of a tectonic stratigraphy in which original plutonic distributions have been structurally modified. This impression is independently supported by vertical seismic profile studies (Leary, et al., this volume). We would also suggest that there are important low-angle 
structures which predate the entire sedimentary section. As noted, low-angle foliations consistently observed in the Cretaceous granitoids and older gneisses developed in or prior to the Cretaceous as part of a complex plutonic and high temperature (amphibolite facies) metamorphic history. Clasts of these foliated rocks are found in the unmetamorphosed late Cretaceous (?) San Francisquito Formation which rests in depositional unconformity on similar gneisses.

The importance of low angle structures in southern California geology has been emphasized by Ehlig (1968), Silver (1982), and by seismic reflection studies. We believe the Cajon Pass hole can contribute critical information to such interpretations.

\section{Summary}

A usable plutonic stratigraphy which occurs in both the DOSECC and Arkoma wells appears to be of tectonic origin. It can be used to decipher some of the important local structural features which appear to have developed in several generations of Neogene faulting, both high and low-angle. Surface structures may be tectonically decoupled from deeper sedimentary and basement structural features. Cretaceous or older low-angle structures are also recorded in the plutonic and metamorphic rocks found in both wells.

Acknowledgements. Robert Johnson, DOSECC engineer, supplied the well-survey information presented in Figure 1 and incorporated in Figure 2. R. Weldon, P. Pezard and K. Meisling have been generous in sharing their ideas and experience as well as providing preprints of important papers. $M$. Zoback provided geophysical logs for the Arkoma hole as well as extensive discussions. Weldon and Meisling provided thoughtful reviews. This work supported by the National Science Foundation and DOSECC. Contribution No.4636, Division of Geological and Planetary Sciences, California Institute of Technology.

\section{References}

Ehlig, P. L., Causes of distribution of Pelona, Rand, and Orocopia Schist along the San Andreas and Garlock faults, in Dickinson, W.R., and Grantz, A., eds., Proceedings of the Conference on Geologic Problems of the San Andreas Fault System: Stanford Univ. Pub. Geol. Sci., 11, 294, 1968.

Lachenbruch, A. and Sass, J., The stress heat flow paradox and thermal results from Cajon Pass,Geophys. Res. Lett., this volume. 1988.

Leary, P., Henyey, T., and Li, Y-G. Fracture related reflectors in basement rock from vertical seismic profiling at Cajon Pass, Geophys. Res. Lett., this volume. 1988.

Meisling, K.E. and Weldon, R.J., Late Cenozoic tectonics of the northwestern San Bernardino Mountains, southern California: Geol. Soc. America Bull., in press, 1988.

Pezard, P. A., Weldon, R. J., Anderson, R.N., Wilkinson, C., and Ollier, R. R., 1988, Constraints on a structural model for the sedimentary section at the Cajon Pass Scientific Drillsite, California: Geophys. Res. Lett., this volume. 1988.

Silver L.T., Evidence and a model for west-directed early Cenozoic basement overthrusting in southern California: Geol. Soc. Am. Abstr. Programs, 14, 617, 1982.

Silver, L.T., and James, E.W., Geologic setting and lithologic column of the Cajon Pass Deep Drillhole, Geophys. Res. Lett., this volume, 1988.

Eric W. James and Leon T. Silver, Division of Geological and Planetary Sciences, California Institute of Technology, Pasadena, CA 91125.

(Received April 6, 1988; revised July 14, 1988; accepted July 14, 1988.) 